\title{
Ubiquinone limits oxidative stress in Escherichia coli
}

\author{
Britta Søballe and Robert K. Poole
}

Krebs Institute for Biomolecular Research, Department of Molecular Biology and Biotechnology, The University of Sheffield, Firth Court, Western Bank Sheffield S10 2TN, UK
Author for correspondence: Robert K. Poole. Tel: +44 114222 4447. Fax: +44 1142728697. e-mail:r.poole@sheffield.ac.uk

Ubiquinone is an essential redox component of the aerobic respiratory chains of bacteria and mitochondria. It is well established that mammalian ubiquinone can function in its reduced form (ubiquinol) as a lipid-soluble antioxidant preventing lipid peroxidation. The objective of this study was to test the hypothesis that prokaryotic ubiquinone is involved in the defence against oxidative stress in the cytoplasmic membrane. The rate of superoxide production by rapidly respiring wild-type Escherichia coli membranes was twofold higher than in the slowly respiring membranes from a ubiCA knockout mutant. However, large amounts of superoxide accumulated in the $\mathrm{Ubi}^{-}$ membranes compared to wild-type membranes, which possess superoxidescavenging ubiquinol. Likewise, the rate of $\mathrm{H}_{2} \mathrm{O}_{2}$ production was twofold higher in the wild-type, but the overall production of $\mathrm{H}_{2} \mathrm{O}_{2}$ was again significantly higher in the Ubi- membranes. Inclusion of a water-soluble ubiquinone homologue (UQ-1) effectively decreased the amount of $\mathrm{H}_{2} \mathrm{O}_{2}$ produced in the $\mathrm{Ubi}^{-}$membranes in a concentration-dependent manner. Addition of UQ-2 to the membranes was even more effective in limiting accumulation of $\mathrm{H}_{2} \mathrm{O}_{2}$ than was UQ-1, suggesting a role for the side-chain in conferring liposolubility in the antioxidative defence mechanism. Intracellular $\mathrm{H}_{2} \mathrm{O}_{2}$ concentration was increased 1.8-fold in the ubiCA mutant, and expression of the katG gene, encoding the catalase hydroperoxidase $I$, as well as catalase enzyme activity, were increased twofold in this mutant. The ubiCA mutant was hypersensitive to oxidative stress mediated by $\mathrm{CuSO}_{4}$ or $\mathrm{H}_{2} \mathrm{O}_{2}$; sensitivity to the latter could be abolished by addition of cysteine. This phenotype was also exhibited by a ubiG mutant, defective in the last step of UQ biosynthesis and therefore expected to accumulate several UQ biosynthetic intermediates. These observations support the participation of reduced ubiquinone as an antioxidant in E. coli. The ubiCA mutant exhibited a pleiotropic phenotype, being resistant to heat, linolenic acid and phleomycin. Resistance to the two latter compounds is probably due to reduced uptake. Like mutants unable to synthesize the quinol oxidase, cytochrome bd, the ubicA mutant was also sensitive to dithiothreitol, an effect that is attributed to inability of the respiratory chain to maintain an appropriate redox balance in the periplasm.

Keywords: ubiquinone, Escherichia coli, superoxide, peroxide, oxidative stress

\section{INTRODUCTION}

Ubiquinone (Coenzyme $Q$ or UQ) is a lipid-soluble component of membrane-bound electron-transport chains, where it is present in large molar excess over

Abbreviations: HRP, horseradish peroxidase; SOD, superoxide dismutase; $\mathrm{UQ}$, ubiquinone; $\mathrm{UQH}_{2}$, ubiquinol (fully reduced form). other respiratory components (Søballe \& Poole, 1999). In animal cells, UQ is found not only in the inner mitochondrial membrane, but also in endoplasmic reticulum, Golgi, lysosomes, peroxisomes, and plasma membrane (Kalén et al., 1989). Recently, eukaryotic UQ has acquired renewed interest due to the increasing body of evidence suggesting that reduced UQ (i.e. ubiquinol or $\left.\mathrm{UQH}_{2}\right)$ is able to function as a lipid-soluble anti- 
oxidant (for a review, see Ernster \& Dallner, 1995). $\mathrm{UQH}_{2}$ scavenges lipid peroxyl radicals and thereby prevents a chain reaction causing oxidative damage to polyunsaturated fatty acids of biological membranes, a process known as lipid peroxidation (Forsmark-Andrée et al., 1995). The amount of $\mathrm{UQH}_{2}$ and other antioxidants, such as vitamin E, present in low-density lipoprotein, is of vital importance for the prevention of atherosclerosis. The $\mathrm{UQH}_{2}$ form is maintained by quinone reductases (e.g. hepatocyte DT-diaphorase and lipoamide dehydrogenase) and thus protects against cytotoxic and carcinogenic effects (Beyer et al., 1996; Olsson et al., 1999). Inhibition of quinone reductase activity results in an increase in free radical damage (Beyer et al., 1996). The antioxidant properties of $\mathrm{UQH}_{2}$ have led to its clinical use in the treatment of various diseases, e.g. heart disease (Ernster \& Dallner, 1995).

In the facultatively anaerobic bacterium Escherichia coli, UQ with an 8-unit isoprenoid side-chain is an essential component of the aerobic respiratory chain, whereas an alternative quinone, menaquinone or $\mathrm{MQ}$, is more functional in anaerobic respiration (Gennis \& Stewart, 1996). The most commonly shown scheme for the sequence of carriers in the aerobic respiratory chains consists of a single UQ pool located immediately upstream of the oxidases and downstream of the respiratory dehydrogenases (e.g. Gennis \& Stewart, 1996). However, this scheme may be oversimplified, since we recently demonstrated that UQ also functions as electron carrier between cytochromes $b$ and the terminal oxidases by using dual-wavelength spectrophotometry to monitor cytochrome reduction levels in a UQ-deficient strain (ubiCA) (Søballe \& Poole, 1998). The $u b i C A$ operon encodes the enzymes chorismate lyase and 4-hydroxybenzoate transferase for the first two committed steps of UQ biosynthesis (Søballe \& Poole, 1999).

There remains controversy as to whether respiratorychain quinones and quinone-like compounds such as menadione or anthracycline antibiotics might actually stimulate superoxide production (see Afanas'ev et al., 1990). In E. coli, it was recently demonstrated that NADH dehydrogenase II is a major source of superoxide and hydrogen peroxide production by autoxidation of its reduced FAD cofactor (Messner \& Imlay, 1999). Membranes from a UQ- and MQ-deficient mutant produced more superoxide and peroxide; this was attributed to electrons 'backing up' at $\mathrm{NADH}$ dehydrogenase II. Sulfite reductase was found to be a second flavin-containing autoxidizable electron-transport enzyme of E. coli (Messner \& Imlay, 1999). However, in bacteria, it is still not clear whether, in addition to its respiratory roles, $\mathrm{UQH}_{2}$ acts as an antioxidant or pro-oxidant. E. coli does contain a quinone oxidoreductase (Qor) (Thorn et al., 1995), which may be important in maintaining UQ in its fully reduced state by 2-electron reductions, but the role of this enzyme is unknown. In Saccharomyces cerevisiae, a UQ-deficient strain showed enhanced sensitivity to products of autoxidized polyunsaturated fatty acids, indicating a protective role of $\mathrm{UQH}_{2}$ (Do et al., 1996).

Some studies directed at determining the roles of quinones in bacterial physiology (e.g. Imlay, 1995) have used UQ-deficient mutants isolated after chemical mutagenesis, which are recognized to be unstable or leaky. Therefore, we have used a stable knockout mutant having a deletion and insertion at the junction of the $u b i C$ and $u b i A$ genes (Søballe \& Poole, 1998) and tested the hypothesis that UQ in E. coli acts as an antioxidant in the cell's defence against oxygen-derived radicals and oxidative stress in the cytoplasmic membrane.

\section{METHODS}

Bacterial strains and growth conditions. The E. coli strains used in this work are described in Table 1. P1 transductions were performed using a modification of the protocol of Miller (see Poole et al., 1996). All cultures were grown at $37^{\circ} \mathrm{C}$ with vigorous shaking (200 r.p.m.) in conical flasks containing onefifth their volume of medium. Culture optical density was measured with a Pye-Unicam SP6-550 spectrophotometer at $600 \mathrm{~nm}$. However, cultures for $\beta$-galactosidase assays were grown in $250 \mathrm{ml}$ flasks with matched glass tubes of Klett dimensions as a side arm and the culture densities were measured with a Klett-Summerson photoelectric colorimeter (Manostat Corp.) fitted with a red filter.

Growth media were prepared as described by Poole et al. (1996). For membrane preparations, strains MG1655 (wildtype) and RKP4152 (ubiCA) were grown aerobically in LB with $0.5 \%(\mathrm{w} / \mathrm{v})$ xylose and harvested at $\mathrm{OD}_{600} 0.55$. For catalase assays, the strains were also grown to exponential phase $\left(\mathrm{OD}_{600} 0.5\right)$ but in LB with $40 \mathrm{mM}$ glucose. For $\beta$ galactosidase assays, strains were grown in $10 \mathrm{ml} \mathrm{LB}$ with $40 \mathrm{mM}$ xylose added. Strains were treated with paraquat $(50 \mu \mathrm{M})$ or $\mathrm{H}_{2} \mathrm{O}_{2}(50 \mu \mathrm{M})$ at 50 Klett units and harvested in the exponential phase of growth at 100 Klett units.

Viable counts were performed after treating mid-exponential cultures of wild-type and $u b i$ cells grown in MOPS/glucose $(40 \mathrm{mM})$ medium with $0.03 \%(\mathrm{w} / \mathrm{v}) \mathrm{H}_{2} \mathrm{O}_{2}$ or phleomycin $\left(10 \mu \mathrm{g} \mathrm{ml}^{-1}\right)$. Heat resistance was analysed by aerobic shock treatment at $52{ }^{\circ} \mathrm{C}$. A portion $(0.5 \mathrm{ml})$ of a mid-exponential

Table 1. E. coli strains used in this study

\begin{tabular}{|c|c|c|}
\hline Strain & Relevant genotype & Reference or source \\
\hline MG1655 & $\begin{array}{l}\mathrm{F}^{-} \text {, referred to as } \\
\text { wild-type }\end{array}$ & Laboratory collection \\
\hline RKP4152 & $u b i C A:: \mathrm{Km}$ & Søballe \& Poole (1998) \\
\hline QC772 & $\begin{array}{c}\Phi(\operatorname{sod} A-l a c Z) \\
\text { slacU rpsL }\end{array}$ & Touati (1988) \\
\hline RKP4228 & $\begin{array}{l}\text { As QC772 but } \\
\text { ubiCA::Km }\end{array}$ & This work \\
\hline BGF931 & $\operatorname{Tet}^{\mathrm{r}} \Phi(k a t G-I a c Z)$ & $\begin{array}{l}\text { Bruce Demple, Harvard } \\
\text { School of Public Health, } \\
\text { Boston, MA, USA }\end{array}$ \\
\hline RKP4241 & $\begin{array}{c}\text { As BGF931 but } \\
u b i C A:: \mathrm{Km}\end{array}$ & This work \\
\hline HW271 & $\mathrm{F}^{-} u b i G$ zei:: $\operatorname{Tn} 10$ & Wu et al. (1992) \\
\hline HW272 & $\mathrm{F}^{-} z e i:: \operatorname{Tn} 10$ & Wu et al. (1992) \\
\hline
\end{tabular}


culture was transferred to $4.5 \mathrm{ml}$ MOPS/glucose medium, preincubated at $52{ }^{\circ} \mathrm{C}$, and shaken at this temperature. When exposed to $\mathrm{CuSO}_{4}(5 \mathrm{mM})$ or linolenic acid $(1 \mathrm{mM})$ the strains were grown in LB medium with xylose $(40 \mathrm{mM})$. Samples of all the treated cultures were taken at appropriate time intervals and a dilution series $\left(10^{-1}\right.$ to $\left.10^{-6}\right)$ was performed in $0.9 \%$ $\mathrm{NaCl}$. A portion $(20 \mu \mathrm{l})$ of each dilution was spotted on LB agar plates and incubated at $37^{\circ} \mathrm{C}$ overnight. DTT sensitivity studies were performed as described by Goldman et al. (1996a). Wild-type and ubi mutant cells were streaked on nutrient agar plates containing various concentrations of DTT $(0 \cdot 8-24 \mathrm{mM})$ and grown at $30^{\circ} \mathrm{C}$ for $2 \mathrm{~d}$. To obtain aerobic growth curves, three flasks were inoculated with $1 \%$ of an overnight culture of wild-type or $u b i C A$ cells in LB with glucose $(40 \mathrm{mM})$. To one of the flasks was added $\mathrm{H}_{2} \mathrm{O}_{2}$ to a final concentration of $2.5 \mathrm{mM}$, whereas to another was added $\mathrm{H}_{2} \mathrm{O}_{2}(2.5 \mathrm{mM})$ plus cysteine to a final concentration of $0.83 \mathrm{mM}$.

Preparation of membranes. This was performed as described by Søballe \& Poole (1998). Protein concentrations were determined by the method of Markwell et al. (1978).

Superoxide anion detection. The rate of $\mathrm{O}_{2}^{--}$production during reactions in vitro was measured as the superoxide dismutase (SOD)-sensitive rate of cytochrome $c$ reduction (Imlay \& Fridovich, 1991) in a Beckman DU 650 spectrophotometer. The $1 \mathrm{ml}$ reaction cuvette contained $50 \mathrm{mM}$ potassium phosphate buffer, $20 \mu \mathrm{M}$ cytochrome $c$, and wildtype or $u b i$ membranes $\left(200 \mu \mathrm{g}\right.$ protein $\mathrm{ml}^{-1}$, final concentration). Reduction of cytochrome $c$ was initiated by the addition of $100 \mu \mathrm{M}$ NADH (final concentration) and monitored spectrophotometrically at $550 \mathrm{~nm}$. Duplicate reactions were performed with the addition of 250 units SOD (Sigma). The extent of cytochrome reduced was calculated using an absorption coefficient, $\varepsilon$, of $21 \cdot 0 \mathrm{mM}^{-1} \mathrm{~cm}^{-1}$.

$\mathrm{H}_{2} \mathrm{O}_{2}$ production. The amount of $\mathrm{H}_{2} \mathrm{O}_{2}$ produced by respiring membranes was measured using the scopoletin assay in a Hitachi F-2500 fluorescence spectrophotometer in time-scanning mode with excitation at $350 \mathrm{~nm}$ and emission at $460 \mathrm{~nm}$ (Loshen et al., 1971). The reaction $\operatorname{mix}(2.5 \mathrm{ml})$ in phosphatebuffered saline (PBS) buffer contained membranes $(200 \mu \mathrm{g}$ protein $\mathrm{ml}^{-1}$, wild-type or $u b i C A$ ) and $0.76 \mu \mathrm{M}$ horseradish peroxidase (HRP). The fluorescent substrate scopoletin was added to a final concentration of $0 \cdot 2 \mu \mathrm{M}$ and the reaction was initiated by addition of $25 \mathrm{mM}$ glucose. The amount of $\mathrm{H}_{2} \mathrm{O}_{2}$ generated was determined from a standard curve, in which the $\mathrm{H}_{2} \mathrm{O}_{2}$ concentration $(0-0 \cdot 15 \mathrm{M})$ was directly proportional to the quenching of scopoletin fluorescence. When indicated, water-soluble ubiquinone (UQ-1 or UQ-2, purchased from Sigma) was added to a final concentration of $0 \cdot 2-2 \cdot 0 \mu \mathrm{M}$ (from a $10 \mathrm{mM}$ stock in 1:1 ethanol/water) before the reaction was initiated by the addition of $5 \mathrm{mM}$ glycerol.

Determination of intracellular $\mathrm{H}_{2} \mathrm{O}_{2}$ production was based on the assumption that free diffusion of $\mathrm{H}_{2} \mathrm{O}_{2}$ through the cell membrane allows an equilibrium to occur after about $15 \mathrm{~min}$ (Gonzalez-Flecha \& Demple, 1994). Cells from $2.5 \mathrm{ml}$ of a culture of the wild-type or $u b i C A$ strain, grown in LB to the exponential phase (50 Klett units), were harvested and resuspended in $25 \mathrm{ml}$ phosphate-buffered saline. Samples were taken at 5 min intervals and spun briefly in a microfuge before assaying the $\mathrm{H}_{2} \mathrm{O}_{2}$ content of the supernatant using the above fluorometric assay.

Catalase assay. Cell pellets were washed in $100 \mathrm{mM}$ potassium phosphate buffer $(\mathrm{pH} 7 \cdot 0$ ) and disrupted by sonication (five periods of $1 \mathrm{~min}$ each). Cell debris and unbroken cells were removed by centrifugation in a microfuge for $30 \mathrm{~min}$ at 13000 r.p.m. The protein concentration of the supernatant extract was determined by the method of Markwell et al. (1978). The catalase activity was measured by monitoring $\Delta A$ at $240 \mathrm{~nm}$ in time-scanning mode in a Beckman DU 650 spectrophotometer (Gonzalez-Flecha \& Demple, 1994). The $1 \mathrm{ml}$ UV-cuvette contained $510 \mu \mathrm{g}$ supernatant protein in potassium phosphate buffer and the reaction was initiated by adding $\mathrm{H}_{2} \mathrm{O}_{2}$ to a final concentration of $5 \mathrm{mM}$. The initial rate of decomposition of $\mathrm{H}_{2} \mathrm{O}_{2}$ was determined using an $\varepsilon_{240}$ of $43.6 \times 10^{-3} \mathrm{mM}^{-1} \mathrm{~cm}^{-1}$. One unit of catalase activity is defined as the change in $\mathrm{H}_{2} \mathrm{O}_{2}$ concentration $(\mathrm{mM})$ per min.

$\boldsymbol{\beta}$-Galactosidase assays. Assays were carried out at room temperature as described before (Søballe \& Poole, 1997). Each culture was assayed in triplicate; results were confirmed in at least two independent experiments.

\section{RESULTS AND DISCUSSION}

\section{UQ limits accumulation of superoxide generated in aerobic respiration}

A major site of $\mathrm{O}_{2}^{--}$generation in E. coli is the respiratory chain of the cell membrane (Gonzalez-Flecha \& Demple, 1995; Imlay, 1995). To study the role of UQ in this process, $\mathrm{O}_{2}^{--}$was quantified by $\mathrm{NADH}$-induced, SODsensitive cytochrome $c$ reduction at $550 \mathrm{~nm}$ using membrane preparations of the wild-type (MG1655) and a UQ-deficient strain (ubiCA, RKP4152). Addition of SOD inhibited the initial rate of cytochrome $c$ reduction by $44 \%$ in the wild-type and by $36 \%$ in the $u b i C A$ mutant. SOD-insensitive reduction of cytochrome $c$ presumably reflects direct interaction with respiratory chain components. Additional quantities of SOD did not further decrease the rate of cytochrome $c$ reduction. The initial rate of $\mathrm{O}_{2}^{--}$production expressed per mg membrane protein in the $u b i C A$ mutant was about half of that in wild-type cells (Fig. 1; Table 2). However, the respiration rate of NADH-treated membrane preparations is decreased in $u b i C A$ mutants by about $80 \%$

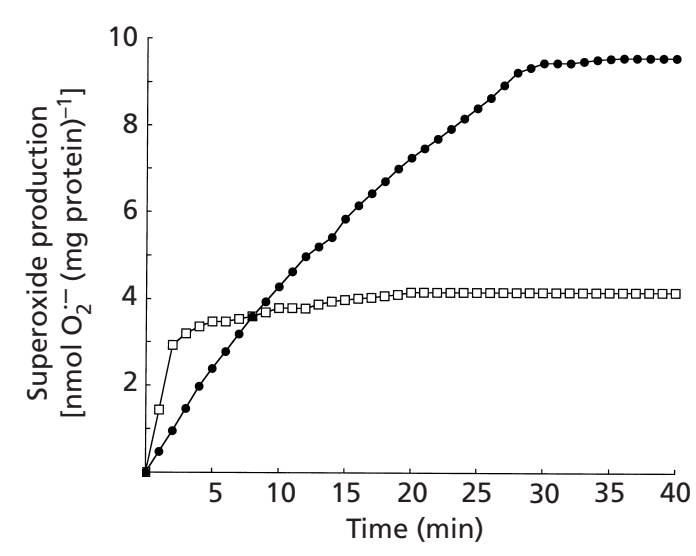

Fig. 1. Effect of UQ deficiency on superoxide production. The SOD-sensitive rate of cytochrome $c$ reduction was measured in membranes from wild-type ( $\square$ ) and ubi (O) strains. The reaction, containing $20 \mu \mathrm{M}$ cytochrome $c$ and $0.2 \mathrm{mg}$ membrane protein $\mathrm{ml}^{-1}$, was initiated by NADH $(100 \mu \mathrm{M})$ and monitored at $550 \mathrm{~nm}$. The results shown are typical of three similar determinations. 
Table 2. Effects of UQ deficiency on superoxide and $\mathrm{H}_{2} \mathrm{O}_{2}$ production and metabolism

Production of $\mathrm{O}_{2}^{--}$and $\mathrm{H}_{2} \mathrm{O}_{2}$ and catalase activities were measured as described in Methods. The $\mathrm{O}_{2}^{--}$assay was repeated twice and a typical set of values is given, corresponding to Fig. 1. The values for $\mathrm{H}_{2} \mathrm{O}_{2}$ and catalase activity are means of three separate experiments.

\begin{tabular}{|c|c|c|c|c|c|c|}
\hline \multirow[t]{2}{*}{ Strain } & \multicolumn{2}{|c|}{ SOD-sensitive $\mathrm{O}_{2}^{--}$production } & \multicolumn{3}{|c|}{$\mathrm{H}_{2} \mathrm{O}_{2}$ production } & \multirow{2}{*}{$\begin{array}{c}\text { Catalase } \\
\text { activity } \\
\left(\mathrm{H}_{2} \mathrm{O}_{2} \text { converted, }\right. \\
\left.\text { units } \mathrm{mg}^{-1}\right)\end{array}$} \\
\hline & $\begin{array}{c}\text { Initial rate } \\
\text { of } \mathrm{O}_{2}^{--} \\
\left(\mathrm{nmol} \mathrm{min}^{-1} \mathrm{mg}^{-1}\right)\end{array}$ & $\begin{array}{c}\text { Total amount } \\
\text { of } \mathrm{O}_{2}^{--} \\
\left(\mathrm{nmol} \mathrm{mg}^{-1}\right)\end{array}$ & $\begin{array}{c}\text { Initial rate of } \\
\mathrm{H}_{2} \mathrm{O}_{2} \text { production } \\
\text { in membranes } \\
\left(\mathrm{nmol} \mathrm{min}^{-1} \mathrm{mg}^{-1}\right)\end{array}$ & $\begin{array}{c}\text { Accumulation of } \\
\mathrm{H}_{2} \mathrm{O}_{2} \text { in } \\
\text { membranes } \\
\left(\mathrm{nmol} \mathrm{mg}^{-1}\right)\end{array}$ & $\underset{(\mu \mathrm{M})}{\text { Intracellular }} \mathrm{H}_{2} \mathrm{O}_{2}$ & \\
\hline Wild-type & $1 \cdot 5$ & $4 \cdot 2$ & $0 \cdot 46$ & $0 \cdot 43$ & 14 & $2 \cdot 7$ \\
\hline ubiCA & $0 \cdot 7$ & $9 \cdot 6$ & $0 \cdot 29$ & $0 \cdot 84$ & 25 & $5 \cdot 2$ \\
\hline
\end{tabular}

(Søballe \& Poole, 1998) and therefore correction of Fig. 1 for the electron transfer rates to $\mathrm{O}_{2}$ would emphasize the antioxidant role of UQ. Fig. 1 also shows that the rapid production of $\mathrm{O}_{2}^{--}$in the wild-type strain ceased after about $2-3 \mathrm{~min}$, whereas in the $u b i C A$ strain, $\mathrm{O}_{2}^{--}$ production continued until the cytochrome $c$ present in the assay was fully reduced (Fig. 1). Thus, the total amount of $\mathrm{O}_{2}^{--}$produced expressed per mg membrane protein was $2 \cdot 3$-fold higher in the ubiCA mutant compared to the wild-type strain (Table 2) under these assay conditions. This result clearly indicates the importance of UQ in maintaining low $\mathrm{O}_{2}^{--}$levels.

Messner \& Imlay (1999) used vesicles produced from a chemically produced ubiA mutant (AN385) and found a high rate of $\mathrm{O}_{2}^{--}$production when expressed per electron transferred to $\mathrm{O}_{2}$. Titration of the substrate for UbiA (4hydroxybenzoate) to the growing $u b i A$ culture resulted in the production of UQ, increasing respiration rate and causing a decrease in the rate of $\mathrm{O}_{2}^{--}$production.

\section{UQ limits accumulation of $\mathrm{H}_{2} \mathrm{O}_{2}$ in vitro}

$\mathrm{H}_{2} \mathrm{O}_{2}$ production in membranes from wild-type and ubiCA cells was measured using a HRP-dependent assay, in which the quenching of the fluorescent substrate scopoletin is directly proportional to the production of $\mathrm{H}_{2} \mathrm{O}_{2}$ (not shown). The initial rate of $\mathrm{H}_{2} \mathrm{O}_{2}$ production was $37 \%$ lower in the ubiCA mutant compared to the wild-type (Table 2). However, in the ubiCA membranes, all the available scopoletin was quenched within 6 min (Fig. 2b), whereas the substrate was only $50 \%$ quenched in the wild-type strain in the same time period (Fig. 2a); overall, there was a twofold increase in the accumulation of $\mathrm{H}_{2} \mathrm{O}_{2}$ in the ubiCA mutant under these assay conditions (Fig. 2, Table 2).

The effects on $\mathrm{H}_{2} \mathrm{O}_{2}$ production of adding a watersoluble ubiquinone homologue, UQ-1, to the $u b i$ membranes are shown in Fig. 3(a). Over the assay period, the accumulation of $\mathrm{H}_{2} \mathrm{O}_{2}$ decreased substantially with increasing additions of UQ-1; accumulation of $\mathrm{H}_{2} \mathrm{O}_{2}$ decreased by $80 \%$ in the presence of $2 \mu \mathrm{M}$ UQ- 1 . On addition of $0.4 \mu \mathrm{M}$ UQ-1 [corresponding to $2 \mathrm{nmol}(\mathrm{mg}$ protein) ${ }^{-1}$ ], $\mathrm{H}_{2} \mathrm{O}_{2}$ accumulation decreased by $50 \%$ to a

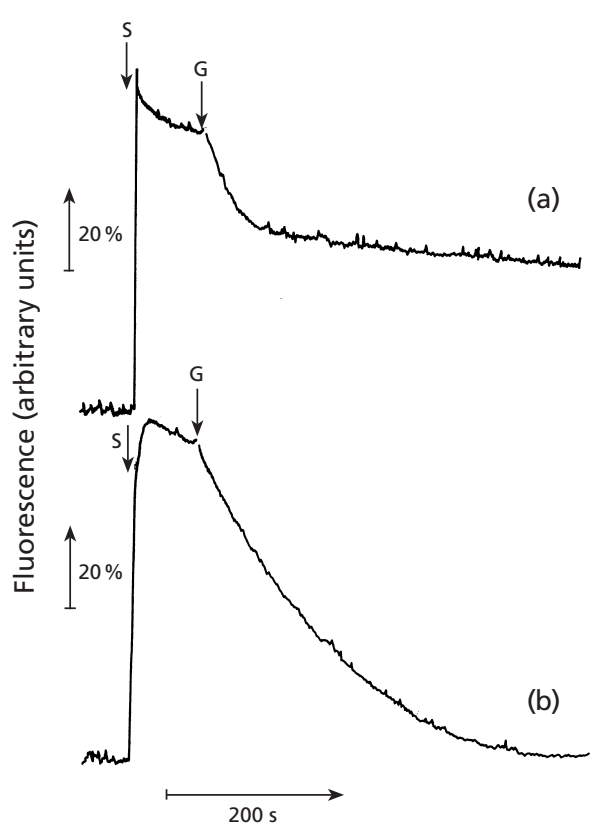

Fig. 2. Effect of $U Q$ deficiency on $\mathrm{H}_{2} \mathrm{O}_{2}$ production. Quenching of the fluorescent substrate scopoletin by glucose-respiring membranes from wild-type (a) and ubi (b) cells was followed in a fluorescence spectrophotometer in time-scanning mode, with excitation at $350 \mathrm{~nm}$ and emission at $460 \mathrm{~nm}$. The assay contained $0.2 \mathrm{mg}$ membrane protein $\mathrm{ml}^{-1}$ and $0.76 \mu \mathrm{M}$ HRP. Addition of $0.2 \mu \mathrm{M}$ scopoletin (S) and $25 \mathrm{mM}$ glucose (G) initiated the reaction. The results shown are typical of three similar determinations.

level equivalent to $\mathrm{H}_{2} \mathrm{O}_{2}$ accumulation in wild-type membranes. This is in good agreement with the UQ concentration in membranes from a wild-type strain (AN387) grown aerobically, i.e. about $2 \cdot 26 \mathrm{nmol}(\mathrm{mg}$ protein $)^{-1}$ (Wallace \& Young, 1977). This UQ concentration is anticipated to offer protection against oxidative stress.

In Fig. 3(b) it is shown that ubiquinone with a 2-unit isoprenoid side-chain, UQ-2, decreased $\mathrm{H}_{2} \mathrm{O}_{2}$ accumulation to an even greater extent than UQ-1; addition of 


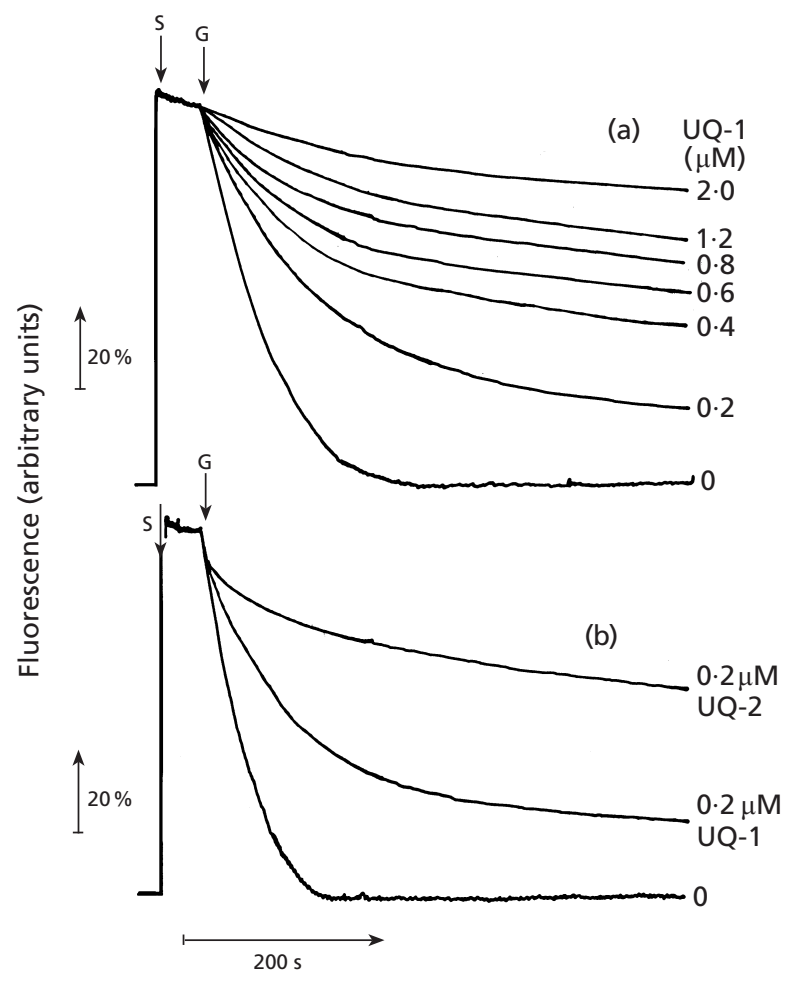

Fig. 3. $\mathrm{H}_{2} \mathrm{O}_{2}$ production in ubi membranes with added $U Q$ homologues, UQ-1 or UQ-2. The scopoletin (S) assay (as described in Fig. 2) was initiated by addition of $5 \mathrm{mM}$ glycerol (G). In (a), various concentrations of UQ-1 $(0 \cdot 2-2 \cdot 0 \mu \mathrm{M})$ were included in the assay. In (b), UQ-1 or UQ-2 was added to a final concentration of $0.2 \mu \mathrm{M}$.

$0 \cdot 2 \mu \mathrm{M}$ UQ-2 decreased the $\mathrm{H}_{2} \mathrm{O}_{2}$ accumulation in the ubi membranes by $57 \%$, whereas $0.2 \mu \mathrm{M}$ UQ-1 decreased it by only $20 \%$. This observation suggests that the length of the side-chain is important in the effectiveness of UQ as an antioxidant. Addition of UQ with longer side-chains, i.e. UQ-6 and UQ-10, was not possible due to their insolubility in water-based assays. In Sacch. cerevisiae, a broad spectrum of UQs (UQ-5 to
UQ-10) has been shown to be biologically functional in a UQ-deficient strain, but the original UQ-6 species showed the highest activity (Okada et al., 1998).

\section{Effects of UQ deficiency on oxidative stress in vivo: peroxide levels, catalase activity and expression of katG and sodA}

The above results demonstrate that isolated membranes from a UQ-deficient strain accumulate substantially more superoxide and peroxide than do membranes containing a normal complement of UQ. To determine if this has physiological consequences for growth, or whether the additional flux of reactive oxygen species can be accommodated by cytoplasmic SOD and catalase activities, we determined the effects of the ubiCA knockout in intact cells.

The steady-state intracellular $\mathrm{H}_{2} \mathrm{O}_{2}$ concentration, which was determined after allowing diffusion of $\mathrm{H}_{2} \mathrm{O}_{2}$ into PBS buffer, was increased $1 \cdot 8$-fold in the $u b i C A$ mutant (Table 2). These results mimic the $\mathrm{O}_{2}^{--}$and $\mathrm{H}_{2} \mathrm{O}_{2}$ measurements in membranes and support a protective role of UQ in oxygen radical scavenging.

We also assayed levels of total catalase activity in unfractionated cell extracts. Rates of $\mathrm{H}_{2} \mathrm{O}_{2}$ conversion were twofold higher in the $u b i C A$ cells compared to wild-type levels (Table 2).

E. coli possesses a bifunctional catalase-peroxidase (HPI, KatG) and a second monofunctional catalase, HPII. HPI, together with an alkyl hydroperoxide reductase, many other proteins with roles in resisting peroxide stress, and a small untranslated RNA are regulated by the OxyR protein in response to peroxide (Demple, 1991; Rosner \& Storz, 1997). The intracellular concentration of $\mathrm{H}_{2} \mathrm{O}_{2}$ in E. coli is normally maintained around $0 \cdot 1-0 \cdot 2 \mu \mathrm{M}$ during aerobic growth and catalase activity is regulated to compensate for changes in $\mathrm{H}_{2} \mathrm{O}_{2}$ production rates (Gonzalez-Flecha \& Demple, 1995). Thus, kat $G$ transcription is a useful measure of intracellular peroxide levels (Gonzalez-Flecha \& Demple, 1995). Table 3 shows that expression of $\Phi(k a t G-$

Table 3. Effect of UQ deficiency on expression of katG and sodA

Mid-exponential cultures of $\Phi(k a t G-l a c Z)$ strains were induced with $\mathrm{H}_{2} \mathrm{O}_{2}(50 \mu \mathrm{M})$, whereas induction of $\Phi(\operatorname{sod} A-l a c Z)$ strains was performed with paraquat $(50 \mu \mathrm{M})$.

\begin{tabular}{|c|c|c|c|}
\hline Strain & Relevant genotype & $\begin{array}{l}\text { Inducer } \\
(+/-)\end{array}$ & $\begin{array}{c}\beta \text {-Galactosidase activity } \\
\text { (Miller units) }\end{array}$ \\
\hline \multirow[t]{2}{*}{ BGF931 } & $\Phi(k a t G-l a c Z)$ & - & 145 \\
\hline & & + & 327 \\
\hline \multirow[t]{2}{*}{ RKP4241 } & $\Phi(k a t G-l a c Z) u b i C A$ & - & 305 \\
\hline & & + & 394 \\
\hline \multirow[t]{2}{*}{ QC772 } & $\Phi(\operatorname{sod} A-l a c Z)$ & - & 1190 \\
\hline & & + & 5070 \\
\hline \multirow[t]{2}{*}{ RKP4228 } & $\Phi(\operatorname{sod} A-l a c Z)$ ubiCA & - & 1000 \\
\hline & & + & 2610 \\
\hline
\end{tabular}




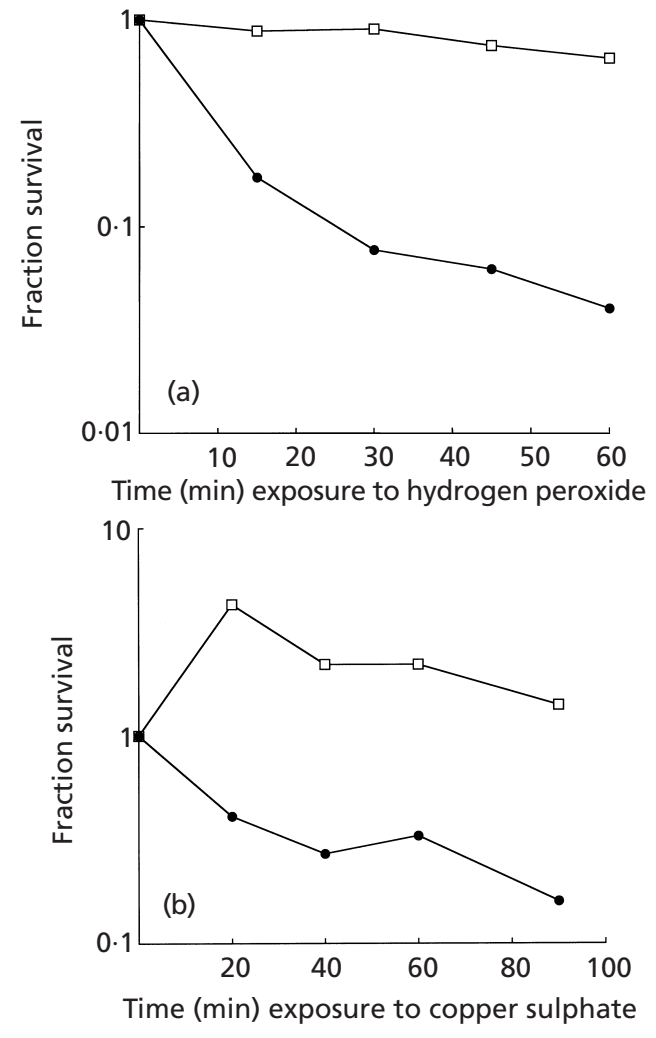

Fig. 4. Sensitivity of the ubi mutant to oxidative stress. Exponential cultures of wild-type $(\square)$ and ubi (O) cells were exposed to $0.03 \% \mathrm{H}_{2} \mathrm{O}_{2}$ (a) and $5 \mathrm{mM} \mathrm{CuSO}_{4}$ (b) and samples for viable counts were taken at appropriate time intervals. The results shown are typical of three similar determinations.

lac $Z$ ) increased $2 \cdot 2$-fold in a wild-type strain when induced with $\mathrm{H}_{2} \mathrm{O}_{2}$ under our experimental conditions. To seek confirmation that the presence of UQ affects $\mathrm{H}_{2} \mathrm{O}_{2}$ levels in vivo, the effect of introducing the $u b i C A$ allele into the $\Phi(k a t G-l a c Z)$ strain was studied. The basal level of $k a t G$ expression was $2 \cdot 1$-fold higher in the $u b i$ background, but induction with $\mathrm{H}_{2} \mathrm{O}_{2}$ still increased the expression a further $1 \cdot 3$-fold (Table 3 ).

The manganese-containing superoxide dismutase (MnSOD) enzyme is encoded by the sodA gene, which can be regarded as a monitor of intracellular oxidative stress as it is induced via sox $R S$ regulators by $\mathrm{O}_{2}^{--}$, by increased oxygen pressure and by redox-active compounds (Touati, 1988; Demple, 1991; Compan \& Touati, 1993). Paraquat is widely used as a redoxcycling agent; it donates a single electron to oxygen to give superoxide anion and is readily rereduced intracellularly, enabling further rounds of superoxide production. The expression of $\Phi(\operatorname{sod} A-l a c Z)$ increased $4 \cdot 2$ fold when induced with paraquat, as expected (Table 3). Surprisingly, the introduction of the ubiCA mutation did not increase the basal level of the aerobic expression of $\operatorname{sod} A$ (Table 3). A possible explanation is that, in vivo, the slow rate of superoxide generation (seen in membranes; Fig. 1) might be accommodated by spon- taneous dismutation of superoxide to peroxide. Thus catalase levels are raised but SOD levels are not. Paraquat increased $\Phi(\operatorname{sod} A-l a c Z)$ expression $2 \cdot 6$-fold in the $u b i$ background (Table 3 ). The fact that paraquat induction was not as marked in the $u b i$ background could be due to the growth defect exhibited by this strain, especially in the presence of severe oxidative stress mediators such as paraquat (not shown). Alternatively, UQ function may be needed for paraquat redoxcycling and $\mathrm{O}_{2}^{\cdot-}$ generation.

\section{A ubiCA mutant is hypersensitive to mediators of oxidative stress}

In view of the elevated levels of superoxide and peroxide measured in $u b i C A$ cells, the ability of cells to tolerate additional exogenous oxidative stress mediated by $\mathrm{H}_{2} \mathrm{O}_{2}$ or $\mathrm{CuSO}_{4}$ was examined (Fig. 4). The ubiCA mutant appeared to be hypersensitive to treatment with $0.03 \%$ $\mathrm{H}_{2} \mathrm{O}_{2}$ and its viability was reduced about 16 -fold relative to the wild-type strain after $1 \mathrm{~h}$ (Fig. $4 \mathrm{a}$ ).

We considered the possibility that intermediates in the UQ biosynthetic pathway downstream of the UbiCAcatalysed steps might act as antioxidants. It has recently been demonstrated that UbiG catalyses both O-methyltransferase steps in UQ biosynthesis, one of which is the last step (Hsu et al., 1996; Poon et al., 1999). However, strains harbouring leaky point-mutant alleles of $u b i G$ (e.g. AN86, AN151; Stroobant et al., 1972) were shown to accumulate demethyl-UQ, the last intermediate in UQ biosynthesis. Unlike RKP4152 (ubiCA knockout strain), HW271 (ubiG) retains considerable respiratory activity with several oxidizable substrates (Wu et al., 1992), suggesting that this strain also harbours a leaky allele. We found that strain HW271 showed increased sensitivity to $\mathrm{H}_{2} \mathrm{O}_{2}$. After $1 \mathrm{~h}$ of $\mathrm{H}_{2} \mathrm{O}_{2}$ treatment, the viability of the $u b i G$ strain was reduced 28 -fold compared to the corresponding wild-type (not shown).

Copper ions $\left(\mathrm{Cu}^{2+} / \mathrm{Cu}^{1+}\right)$ participate in a redox-cycle, resulting in the generation of superoxide anion. They have also been reported to catalyse the conversion of $\mathrm{H}_{2} \mathrm{O}_{2}$ to ${ }^{\circ} \mathrm{OH}$ in vitro (Kimura \& Nishioka, 1997). When treated with $\mathrm{CuSO}_{4}$, the viability of the $u b i C A$ mutant was reduced 10 -fold relative to the wild-type strain after $90 \mathrm{~min}$ (Fig. 4b). Likewise, the viability of the $u b i G$ mutant, HW271, was reduced $4 \cdot 4$-fold after 30 min compared to its isogenic wild-type (not shown). These results indicate the importance of the presence of UQ for protection against oxidative stresses generated by $\mathrm{H}_{2} \mathrm{O}_{2}$ or $\mathrm{CuSO}_{4}$. Sensitivity to oxidative stress in a UQ-deficient mutant of the fission yeast Schizosaccharomyces pombe has also been reported recently (Suzuki et al., 1997).

Cysteine is an amino acid with antioxidant properties due to the presence of the thiol group (Suzuki et al., 1997). Sensitivity of the $u b i C A$ mutant to $\mathrm{H}_{2} \mathrm{O}_{2}(2 \cdot 5 \mathrm{mM})$ could be abolished by the addition of this compound to the growing cells (Fig. 5b). In contrast, the presence of $\mathrm{H}_{2} \mathrm{O}_{2}$ or cysteine did not affect growth of the wild-type 

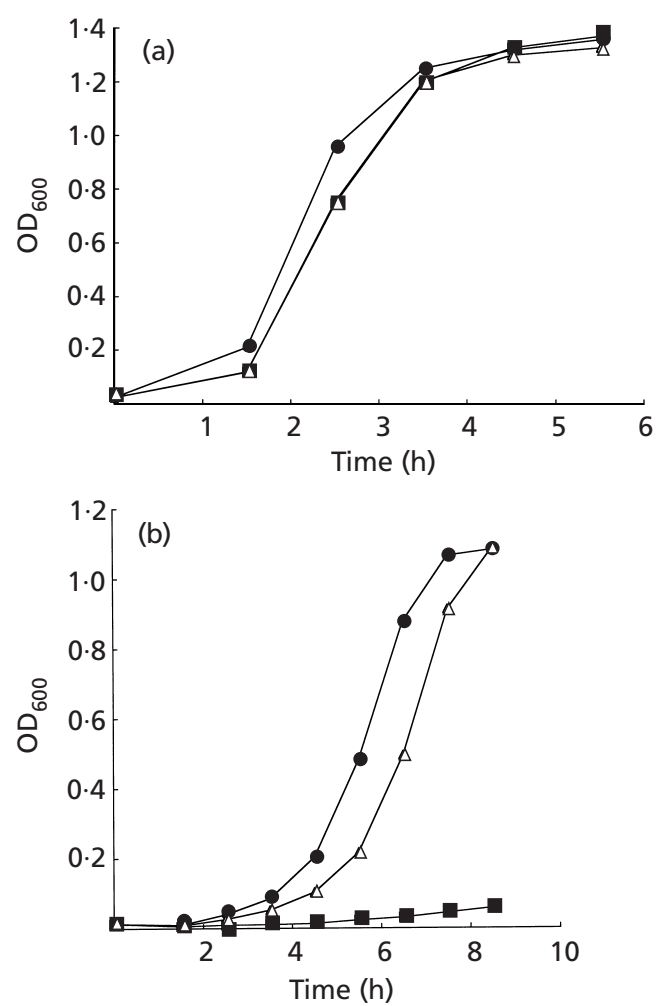

Fig. 5. Rescue of $\mathrm{H}_{2} \mathrm{O}_{2}$ sensitivity of the ubi mutant by cysteine. Growth of (a) the wild-type and (b) the ubiCA strain in LBglucose (O), LB-glucose plus $\mathrm{H}_{2} \mathrm{O}_{2}(2.5 \mathrm{mM})(\boldsymbol{\square})$, and LB-glucose plus both $\mathrm{H}_{2} \mathrm{O}_{2}(2.5 \mathrm{mM})$ and cysteine $(0.83 \mathrm{mM})(\triangle)$. The results shown are typical of three similar determinations.

cells (Fig. 5a). Likewise, cysteine or glutathione restores growth of a UQ-deficient (dps) mutant of fission yeast in minimal medium (Suzuki et al., 1997).

\section{Pleiotropic phenotype of the ubiCA mutant}

Linolenic acid is a polyunsaturated fatty acid prone to autoxidation and breakdown into toxic products (Do et al., 1996); UQ-deficient Sacch. cerevisiae (coq3) and Schiz. pombe have been reported to be hypersensitive to this compound (Do et al., 1996). The hypersensitivity could be abolished by addition of the COQ3 gene on a single-copy plasmid, butylated hydroxytoluene, $\alpha$-tocopherol or trolox, a vitamin E analogue (Do et al., 1996). Surprisingly, when we analysed the sensitivity of E. coli wild-type and $u b i C A$ strains to linolenic acid $(1 \mathrm{mM})$ we found the $u b i C A$ mutant to be highly resistant to this compound, whereas the viability of the wild-type was reduced 500-fold after $3 \mathrm{~h}$ (Fig. 6a).

A similar result was obtained when the cells were treated with phleomycin, which is an antibiotic and antitumour agent produced by Streptomyces verticillus. The drug induces DNA breaks and cell death in prokaryotes and eukaryotes (Collis \& Grigg, 1989). The wild-type and ubiCA strains were treated with phleomycin at a final concentration of $10 \mu \mathrm{g} \mathrm{ml}^{-1}$ (Fig. 6b). The $u b i C A$ strain
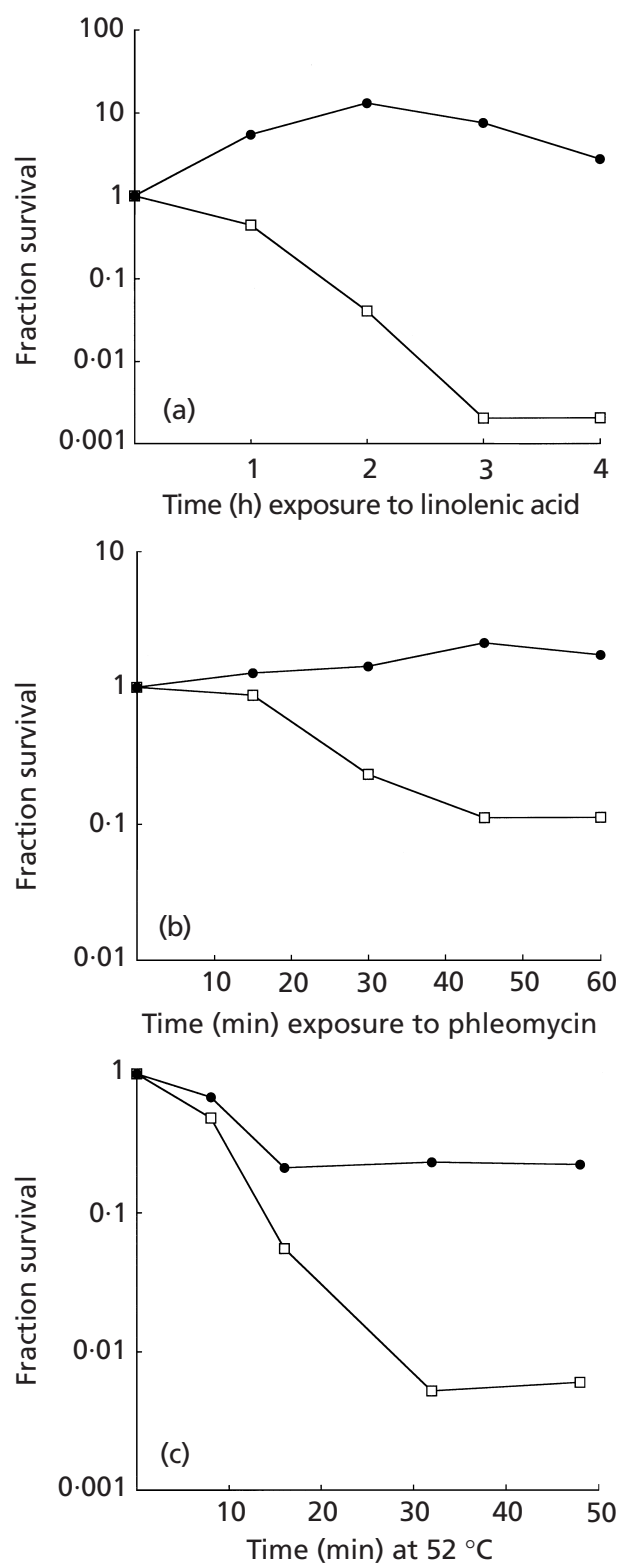

Fig. 6. Pleiotropic phenotype of the ubi mutant. Exponential cultures of wild-type $(\square)$ and $u b i(\bullet)$ strains were exposed to $1 \mathrm{mM}$ linolenic acid (a), $10 \mu \mathrm{g}$ phleomycin $\mathrm{ml}^{-1}$ (b) and heat shock (c) at $52{ }^{\circ} \mathrm{C}$. Samples for viable counts were taken at appropriate time intervals. The results shown are typical of three similar determinations.

appeared resistant to this concentration, whereas the viability of the wild-type was decreased 10 -fold after $1 \mathrm{~h}$ of treatment (Fig. 6b). It is likely that the resistance to both linolenic acid and phleomycin is due to reduced uptake of these compounds in the $u b i C A$ strain.

The effects of heat shock at $52^{\circ} \mathrm{C}$ on the viability of wild-type and $u b i C A$ strains are shown in Fig. $6(\mathrm{c})$. The ubiCA mutant proved to be extremely resistant to the lethal effects of heat shock. After $48 \mathrm{~min}$ at $52^{\circ} \mathrm{C}$ the surviving fraction of the $u b i C A$ mutant was reduced 
$4 \cdot 5$-fold, whereas that of the wild-type was reduced about 170-fold (Fig. 6c).

\section{The ubiCA mutation causes sensitivity to DTT}

Like $u b i$ mutants, mutants (cydAB or $c y d D C$ ) unable to synthesize the quinol oxidase, cytochrome $b d$, have a pleiotropic phenotype, including sensitivity to $\mathrm{H}_{2} \mathrm{O}_{2}$ (Wall et al., 1992; Goldman et al., 1996b). In addition, certain reducing compounds can suppress the temperature-sensitive phenotype of both $c y d A B$ and cydDC mutants. DTT was found to inhibit $\mathrm{Cyd}^{-}$ mutants at 3 and $10 \mathrm{mM}$, concentrations at which the isogenic wild-type strains were resistant (Goldman et al., 1996a, b). A firm explanation for these effects is not available, but it has been suggested (Goldman et al., 1996a) that the thiol periplasmic environment of a $c y d C$ mutant is oxidized in comparison to the wild-type strain. Using the same assay as Goldman et al. (1996a), we found that the $u b i C A$ mutant was sensitive to $8 \mathrm{mM}$ DTT, whereas the wild-type was resistant to DTT at this concentration (not shown). Thiol hypersensitivity has also been reported for $u b i$ mutants isolated after chemical mutagenesis (Zeng et al., 1998). Thus the DTT sensitivity is not due to the ability to assemble cytochrome $b d$ per se, but to respiratory chain function. We hypothesize that $u b i$ mutants are sensitive to DTT because of the requirement for the respiratory chain to oxidize the essential redox-active CXXC motif of DsbB. This membrane protein in turn oxidizes the active-site cysteines in DsbA, the disulfide bond formation factor in the periplasm (Kobayashi \& Ito, 1999). Indeed, ubiA menA mutants and hemA mutants do accumulate a reduced form of DsbA (Kobayashi et al., 1997) and, intriguingly, $d s b A / d s b B$ mutants are sensitive to DTT (Missiakas \& Raina, 1997). These findings and the work of Bader et al. (1999) clearly link the function of the respiratory chain with maintenance of an appropriate redox environment in the periplasm.

\section{Conclusions}

The importance of UQ as a component of E. coli respiratory chains terminated by oxygen and nitrate is well established. The present studies using a defined knockout allele of $u b i C A$ clearly demonstrate additional roles for UQ in limiting the accumulation of superoxide and peroxide. This contradicts the view that quinones might constitute an important source of superoxide by virtue of the spontaneous autoxidation of the radical form (for references, see Afanas'ev et al., 1990). Skulachev (1997) has suggested that respiration that does not involve the Q-cycle - a mechanism that can produce long-lived semiquinone $\left(\mathrm{QH}^{*}\right)$ - might serve as a defence against reactive oxygen species. Further protection from superoxide production in functioning respiratory chains might be afforded by high rates of electron transfer to the terminal oxidase, thereby avoiding 'excessive electronegativity of respiratory carriers' (Papa et al., 1997) and the potential for undesirable single-electron donation to oxygen. Both these conditions appear to be met in E. coli, in which a Q cycle need not be invoked (Poole \& Ingledew, 1987) and in which operation of cytochrome $b d$, which is not a proton pump, allows very rapid rates of respiration with a phenomenally high apparent affinity for oxygen $\left(K_{\mathrm{m}}\right.$ about $5 \mathrm{nM}$; D'mello et al., 1996). Both cyanide (Imlay, 1995) and quinone deficiency (Messner \& Imlay, 1999) increase superoxide production in membrane vesicles, possibly by electron 'leakage' from an upstream component such as NADH dehydrogenase II.

The complex phenotype of $u b i$ mutants is not surprising and arises from at least two important aspects of UQ function. First, UQ is able to limit accumulation of superoxide and peroxide due to its ability to rapidly abstract electrons from upstream dehydrogenases and transfer them to the oxidases. Second, reduced UQ is able to react with superoxide in vitro (Nakayama et al., 1997) and functions as an antioxidant in scavenging oxygen radicals such as perferryls or lipid peroxyl radicals (Ernster \& Dallner, 1995). These studies do not really distinguish between these two mechanisms. Consequent damage in $u b i$ mutants by lipid peroxidation may therefore explain the oxidative-stress-sensitive phenotype and poor growth, as well as the changes in membrane permeability and heat tolerance. Finally, other phenotypes such as sensitivity to DTT are more likely a consequence of impaired respiratory chain function.

\section{ACKNOWLEDGEMENTS}

This work was supported by the Biotechnology and Biological Sciences Research Council (UK) through grant P07744 to R.K.P. We are grateful to Danièle Touati and Bruce Demple for providing strains.

\section{REFERENCES}

Afanas'ev, I. B., Korkina, L. G., Suslova, T. B. \& Soodaeva, S. K. (1990). Are quinones producers or scavengers of superoxide ion in cells? Arch Biochem Biophys 281, 245-250.

Bader, M., Muse, W., Ballou, D. P., Gassner, C. \& Bardwell, C. A. (1999). Oxidative protein folding is driven by the electron transport system. Cell 98, 217-227.

Beyer, R. E., Segura-Aguilar, J., Di Bernard, S. \& 7 other authors (1996). The role of DT-diaphorase in the maintenance of the reduced antioxidant form of coenzyme $\mathrm{Q}$ in membrane systems. Proc Natl Acad Sci USA 93, 2528-2532.

Collis, C. M. \& Grigg, G. W. (1989). An Escherichia coli mutant resistant to phleomycin, bleomycin and heat inactivation is defective in ubiquinone synthesis. J Bacteriol 171, 4792-4798.

Compan, I. \& Touati, D. (1993). Interaction of six global regulators in expression of manganese superoxide dismutase in Escherichia coli K-12. J Bacteriol 175, 1687-1696.

Demple, B. (1991). Regulation of bacterial oxidative stress genes. Annu Rev Genet 25, 315-337.

D'mello, R., Hill, S. \& Poole, R. K. (1996). The cytochrome bd quinol oxidase in Escherichia coli has an extremely high oxygen affinity and two oxygen-binding haems: implications for regulation of activity in vivo by oxygen inhibition. Microbiology 142, $755-763$. 
Do, T. Q., Schultz, J. R. \& Clarke, C. (1996). Enhanced sensitivity of ubiquinone-deficient mutants of Saccharomyces cerevisiae to products of autoxidized polyunsaturated fatty acids. Proc Natl Acad Sci USA 93, 7534-7539.

Ernster, L. \& Dallner, G. (1995). Biochemical, physiological and medical aspects of ubiquinone function. Biochim Biophys Acta 1271, 195-204.

Forsmark-Andrée, P., Dallner, G. \& Ernster, L. (1995). Endogenous ubiquinol prevents protein modification accompanying lipid peroxidation in beef heart submitochondrial particles. Free Radic Biol Med 19, 749-757.

Gennis, R. B. \& Stewart, V. (1996). Respiration. In Escherichia coli and Salmonella: Cellular and Molecular Biology, 2nd edn, pp. 217-261. Edited by F. C. Neidhardt and others. Washington, DC: American Society for Microbiology.

Goldman, B. S., Gabbert, K. K. \& Kranz, R. G. (1996a). Use of heme reporters for studies of cytochrome biosynthesis and heme transport. J Bacteriol 178, 6338-6347.

Goldman, B. S., Gabbert, K. K. \& Kranz, R. G. (1996b). The temperature-sensitive growth and survival phenotypes of Escherichia coli cydDC and $c y d A B$ strains are due to deficiencies in cytochrome $b d$ and are corrected by exogenous catalase and reducing agents. J Bacteriol 178, 6348-6351.

Gonzalez-Flecha, B. \& Demple, B. (1994). Intracellular generation of superoxide as a by-product of Vibrio harveyi luciferase expressed in Escherichia coli. J Bacteriol 176, 2293-2299.

Gonzalez-Flecha, B. \& Demple, B. (1995). Metabolic sources of hydrogen peroxide in aerobically growing Escherichia coli. J Biol Chem 270, 13681-13687.

Hsu, A., Poon, W. W., Shepherd, J. A., Myles, D. C. \& Clarke, C. (1996). Complementation of coq3 mutant yeast by mitochondrial targeting of the Escherichia coli UbiG polypeptide: evidence that UbiG catalyzes both $O$-methylation steps in ubiquinone biosynthesis. Biochemistry 35, 9797-9806.

Imlay, J. A. (1995). A metabolic enzyme that rapidly produces superoxide, fumarate reductase of Escherichia coli. J Biol Chem 270, 19767-19777.

Imlay, J. A. \& Fridovich, I. (1991). Assay of metabolic superoxide production in Escherichia coli. J Biol Chem 266, 6957-6965.

Kalén, A., Norling, B., Appelkvist, E.-L. \& Dallner, G. (1989). Ubiquinone biosynthesis by the microsomal fraction from rat liver. Biochim Biophys Acta 926, 70-78.

Kimura, T. \& Nishioka, H. (1997). Intracellular generation of superoxide by copper sulphate in Escherichia coli. Mutation Res 389, 237-242.

Kobayashi, T. \& Ito, K. (1999). Respiratory chain strongly oxidizes the CXXC motif of DsbB in the Escherichia coli disulfide bond formation pathway. EMBO J 18, 1192-1198.

Kobayashi, T., Kishigama, S., Sone, M., Inokuchi, H., Mogi, T. \& Ito, K. (1997). Respiratory chain is required to maintain oxidised states of the DsbA-DsbB disulfide bond formation system in aerobically growing Escherichia coli. Proc Natl Acad Sci USA 94, 11857-11862.

Loshen, G., Flohe, L. \& Chance, B. (1971). Respiratory chain linked $\mathrm{H}_{2} \mathrm{O}_{2}$ production in pigeon heart mitochondria. FEBS Lett 18, 261-264.

Markwell, M. A. K., Haas, S. M., Bieber, L. L. \& Tolbert, N. E. (1978). A modification of the Lowry procedure to simplify protein determination in membrane and lipoprotein samples. Anal Biochem 87, 206-210.

Messner, K. R. \& Imlay, J. A. (1999). The identification of primary sites of superoxide and hydrogen peroxide formation in the aerobic respiratory chain and sulfite reductase complex of Escherichia coli. J Biol Chem 274, 10119-10128.

Missiakas, D. \& Raina, S. (1997). Protein folding in the bacterial periplasm. J Bacteriol 179, 2465-2471.

Nakayama, T., Hashimoto, M. \& Hashimoto, K. (1997). Superoxide dismutase inhibition of oxidation of ubiquinol and concomitant formation of hydrogen peroxide. Biosci Biotechnol Biochem 61, 2034-2038.

Okada, K., Kainou, T., Matsuda, H. \& Kawamukai, M. (1998). Biological significance of the side chain length in Saccharomyces cerevisiae. FEBS Lett 431, 241-244.

Olsson, J. M., Xia, L., Eriksson, L. C. \& Bjornstedt, M. (1999). Ubiquinone is reduced by lipoamide dehydrogenase and this reaction is potently stimulated by zinc. FEBS Lett 448, 190-192.

Papa, S., Guerrieri, F. \& Capitanio, N. (1997). A possible role of slips in cytochrome $c$ oxidase in the antioxygen defense system of the cell. Biosci Rep 17, 23-31.

Poole, R. K. \& Ingledew, W. J. (1987). Pathways of electrons to oxygen. In Escherichia coli and Salmonella typhimurium: Cellular and Molecular Biology, pp. 170-200. Edited by F. C. Neidhardt and others. Washington, DC: American Society for Microbiology.

Poole, R. K., Anjum, M. F., Membrillo-Hernández, J., Kim, S. O., Hughes, M. N. \& Stewart, V. (1996). Nitric oxide, nitrite, and Fnr regulation of hmp (flavohemoglobin) gene expression in Escherichia coli K-12. J Bacteriol 178, 5487-5492.

Poon, W. W., Barkovich, R. J., Hsu, A. Y., Frankel, A., Lee, P. T., Shepherd, J. N., Myles, D. C. \& Clarke, C. F. (1999). Yeast and rat Coq3 and Escherichia coli UbiG polypeptides catalyze both $\mathrm{O}$ methyltransferase steps in coenzyme Q biosynthesis. J Biol Chem 274, 21665-21672.

Rosner, J. L. \& Storz, G. (1997). Regulation of bacterial responses to oxidative stress. Curr Top Cell Regul 35, 163-175.

Skulachev, V.P. (1997). Membrane-linked systems preventing superoxide formation. Biosci Rep 17, 347-366.

Søballe, B. \& Poole, R. K. (1997). Aerobic and anaerobic regulation of the $u b i C A$ operon, encoding the first two committed steps of ubiquinone biosynthesis in Escherichia coli. FEBS Lett 414, 373-376.

Søballe, B. \& Poole, R. K. (1998). Requirement for ubiquinone downstream of cytochrome(s) $b$ in the oxygen-terminated respiratory chains of Escherichia coli K-12 revealed using a null mutant allele of ubiCA. Microbiology 144, 361-373.

Søballe, B. \& Poole, R. K. (1999). Microbial ubiquinones : multiple roles in respiration, gene regulation and oxidative stress management. Microbiology 145, 1817-1830.

Stroobant, P., Young, I. G. \& Gibson, F. (1972). Mutants of Escherichia coli $\mathrm{K}-12$ blocked in the final reaction of ubiquinone biosynthesis: characterization and genetic analysis. J Bacteriol 109, 134-139.

Suzuki, K., Okada, K., Kamiya, Y., Zhu, X. F., Nakagawa, T., Kawamukai, M. \& Matsuda, H. (1997). Analysis of the decaprenyl diphosphate synthase $(d p s)$ gene in fission yeast suggests a role of ubiquinone as an antioxidant. J Biochem 121, 496-505.

Thorn, J. M., Barton, J. D., Dixon, N. E., Ollis, D. L. \& Edwards, K. J. (1995). Crystal structure of Escherichia coli QOR quinone oxidoreductase complexed with NADPH. J Mol Biol 249, 785-799.

Touati, D. (1988). Transcriptional and posttranscriptional regulation of manganese superoxide dismutase biosynthesis in Escherichia coli, studied with operon and protein fusions. $J$ Bacteriol 170, 2511-2520. 
Wall, D., Delaney, J. M., Fayet, O., Lipinska, B., Yamamoto, T. \& Georgopoulos, C. (1992). arc-dependent thermal regulation and extragenic suppression of the Escherichia coli cytochrome $d$ operon. J Bacteriol 174, 6554-6562.

Wallace, B. J. \& Young, I. G. (1977). Role of quinones in electron transport to oxygen and nitrate in Escherichia coli: studies with a double quinone mutant. Biochim Biophys Acta 461, 84-100.

Wu, G., Williams, H. D., Zamanian, M., Gibson, F. \& Poole, R. K. (1992). Isolation and characterization of Escherichia coli mutants affected in aerobic respiration: the cloning and nucleotide sequence of $u b i G$. Identification of an $S$-adenosylmethioninebinding motif in proteins, RNA, and small-molecule methyltransferases. J Gen Microbiol 138, 2101-2112.

Zeng, H., Snavely, P., Zamorano, P. \& Javor, G. T. (1998). Low ubiquinone content in Escherichia coli causes thiol hypersensitivity. J Bacteriol 180, 3681-3685.

Received 11 August 1999; revised 13 December 1999; accepted 15 December 1999. 